\title{
Street Food around the World: A Review of the Literature
}

\author{
Kouamé Guy Marcel Bouafou'1, Gnakon Flora Carenne Beugrée ${ }^{2}$, Yao Célestin Amani² \\ ${ }^{1}$ Department of Science and Technology, Ecole Normale Supérieure (ENS), Abidjan, Côte d'Ivoire \\ ${ }^{2}$ Institute of Anthropological Development Sciences (ISAD), Félix Houphouet-Boigny University, Abidjan, Côte d'Ivoire \\ Email: publicationbouafou@yahoo.fr
}

How to cite this paper: Bouafou, K. G. M., Beugré, G. F. C., \& Amani, Y. C. (2021). Street Food around the World: A Review of the Literature. Journal of Service Science and Management, 14, 557-575.

https://doi.org/10.4236/jssm.2021.146035

Received: October 15, 2021

Accepted: December 13, 2021

Published: December 16, 2021

Copyright $\odot 2021$ by author(s) and Scientific Research Publishing Inc. This work is licensed under the Creative Commons Attribution International License (CC BY 4.0).

http://creativecommons.org/licenses/by/4.0/

\begin{abstract}
This review aims to analyze the various studies dealing with street food. It is also called "street catering", "the informal food sector", "eating out", "popular catering" or "food outside the home"... The persistence of street food is explained by rapid urbanization and the multiple constraints associated with it: distance between workplaces and home, poverty, lack of transport and canteens in the workplace. This sector provides jobs and allows the poor to eat more cheaply. Consumers of street foods are children, pupils, students, the unemployed, workers, men and women. Street food is sold by women and men, sometimes by children. Street food offers a wide range of foods, with different names, depending on the country. There are breakfast foods based on bread or sandwiches, cereal porridge, donuts, cookies, pastries, dairy products... Then there are the main dishes for lunch or dinner, which are often the traditional foods of family menus, grilled meats and industrial foods. Fruits and vegetables are also sold on the street. In the streets, traditional drinks are more popular than industrial drinks. Street foods are high in fat, carbohydrates and therefore very energetic. The street food sector accounts for $2 \%$ $10 \%$ of jobs in the agricultural economy. Street meals are cheaper (US $\$ 0.1-$ US \$3) and sometimes account for more than $30 \%$ of household food expenditure. The evaluation of good handling practices and the microbial quality of street foods reveals that these foods present risks to the health of consumers and constitute a public health problem. In addition, the use of non-biodegradable plastic packaging for the sale of street food has negative health and environmental consequences. Globally, the street food sector is not regulated. This requires the establishment of control structures to clean up this sector and curb potential health and environmental hazards.
\end{abstract}

\section{Keywords}

Street Food, Actors, Nutritional Value, Risks, Regulation 


\section{Introduction}

Street food has been extensively studied over the past three decades and continues to be studied, given the many scientific publications devoted to it from the 1990s (FAO, 1990; Delisle, 1991; Bricas, 1993; Canet, 1997) to those of the years 2020 (Albuquerque et al., 2020; Kouamé et al., 2020; Meva’a, 2020; Soula et al., 2020; Ferrari et al., 2021; Koffi, 2021). In a context of rapid urbanization of cities and faced with financial constraints, time, regular means of travel and the professional requirements of the populations, street food seems to be imposed on them, with both its advantages and its disadvantages. This review of the literature is being carried out within the framework of the thesis work in progress, the theme of which is "problem of food and nutritional practices of urban populations in precarious neighborhoods of Côte d'Ivoire: case of the municipality of Port-Bouët". It aims to analyze the various studies dealing with street food in certain countries around the world and should highlight aspects insufficiently studied for further study. This will involve 1) defining street food, 2) justifying the persistence of this activity, 3) presenting the players in this sector and 4) the foods sold with their nutritional values, 5) their costs, 6) all exposing the health and environmental risks associated with this business, 7) without forgetting to explore its regulations.

This literature review is based on secondary data sources such as: published books, journals, websites, magazines and annual reports. The keywords for this research are the titles of the various paragraphs discussed here.

\section{Street Food, Approach to Definitions}

The informal food sector has been defined as "the sector producing food and beverages ready to be consumed, prepared and/or sold by vendors, especially in the streets and other similar public places" (FAO, 1990).

Thus, according to Canet (1997), street food enters into the problem of recognizing small market and craft activities in cities. Its place in the urbanization process and in the functioning of the urban economy reflects the way of life and survival in African cities. In Africa and other major cities of the Third World, the sale and consumption of food from outside has several names: "street food", "popular catering", "street food” (Akindes, 1991; FAO, 2007; Secke, 2007).

The meanings of "eating out" take on differentiations depending on the context, as pointed out by Warde and Martens (2000). In speeches, the fact of eating outside essentially refers to four dimensions: a dimension of sociability, an affective dimension, a heritage dimension and a hygienic or sanitary dimension (Warde \& Martens, 2000).

"Eating out" is used to designate all food items that lead to a transaction in a commercial restaurant (Soula et al., 2020).

According to Allen et al. (2018), out-of-home catering brings together street food and catering.

Street food or the informal food sector is one of the links in the food chain 
where it plays an essential role mainly in cities, allowing all socio-professional categories to meet their food needs (Van't Riet et al., 2003; Ohiokpehai, 2003; Kouamé et al., 2020).

Street food is homemade food and junk food consumed outside the home or sold on the street (Albuquerque et al., 2019; Sousa et al., 2019).

In Brazil, street food consists of outlets for ready-to-eat foods sold on the public highway. It's a job (Ferrari et al., 2021).

\section{Street Food: The Reasons for Its Persistence Today}

The expansion of street food (in Africa) is explained by rapid urbanization and the multiple constraints associated with it (distance between workplaces and home, poverty and development of women's activity, the bursting of family solidarity, appearance of new food styles). In addition, for lack of adequate means of transport, of time, of an efficient system of collective catering, such as canteens in the workplace, many Africans buy food on the street, at little cost compared to what they pay. What would a meal cost them in a restaurant or even at home (Canet, 1997).

Staatz and Hollinger (2016) find that in Africa, out-of-home catering is strongly associated with income and is expected to grow faster than other segments of the food industry. This observation is reinforced by Allen et al. (2018): the demand for labor in activities associated with processing, marketing and out-of-home catering is increasing.

As in the Europe, in Algeria, the place of lunch is linked to the organization of the working day. Thus, $24.3 \%$ of Algerians eat lunch at restaurants and $27.2 \%$ at fast food. Out-of-home is still rarely practiced outside of lunch (Chikhi \& Padilla, 2014).

In Benin, consumption outside the home, in particular in the street or in small restaurants, is higher in Cotonou. It begins in the morning and continues until the afternoon. Street food is less in the evening, the main occasion for family meals (Thuillier-Cerdan \& Bricas, 1998).

The rise of out-of-home cooking has several social meanings depending on the socio-economic category of families in Congo. Migration flows to Brazzaville have reinforced socio-economic inequalities between households. On the one hand, popular street food is a means for the poor to eat at a lower cost. On the other hand, out-of-home catering allows the most affluent city dwellers to taste, at will, dishes from elsewhere and quality street food, to limit the constraints of urban life, to discover the cuisines of the world, to have fun or "get a change of scenery" (Berton-Ofouémé, 1993; Soula et al., 2020). The economic crisis, limiting the movements of housewives to the places of sale, the sellers (of lemon, vinegar, oil, salt, avocado, cucumber, green salad, tomato, bread, hard-boiled eggs) are going to meet consumers (Berton-Ofouémé, 1993; Soula et al., 2020).

In Côte d'Ivoire, street food is organized and developed in cities by filling the lack of canteens in public and private companies as well as in schools (Akindès, 
1991). It constitutes an invaluable source of income for the unemployed and especially for women who are generally less educated than men (Berton-Ofoueme, 2007). In Abidjan, the entire urban space is home to women who use the street as a place of work. Three factors have contributed to the increase in the number of these women: the increase in the local population, the expansion of the city and the need to diversify sources of income in all households.

In India, the food system has changed in a few decades. The system of home food production and preservation has shifted to a system based on processed foods packaged and accessible in supermarkets, which have proliferated in cities. The way people access food has also changed, as have the types of advertising and food safety and quality information that consumers are exposed to (High Level Panel of Experts, 2017). In Calcutta, out of 911 street food consumers, 20\% were women working both inside and outside the home, with little time for culinary chores. For these women and their husbands, street food was a solution to their diet during the day (Chakravarty \& Canet, 1994).

At the Jakarta (Indonesia) summit in 1988 on street foods, it was agreed that three formulas could qualify street food: "it is both an instrument of development, a problem to solve and a challenge to be met" (Gerbouin-Rerolle, 1993).

Street food is also an individual means, favored by the anonymity of the city, to escape what is sometimes experienced as family constraints. On the socio-food level, it supports and plays an active role in the evolution of urban food styles (Delisle, 1991; Bricas, 1993).

Traditionally, street food has been part of the Indonesian food model, in both urban and rural settings. The more or less mobile food sales systems have been part of daily eating practices for centuries (Koentjaraningrat, 2007; Protschky, 2008). Today, they present themselves as sources of food security for the poorest (Kolopaking et al., 2011; Steyn et al., 2014; Yulia et al., 2016).

In Jarkata, studies conducted in various poor urban areas (in the global South) have shown that the smaller and poorer the families, the greater the share of the food budget devoted to street food (Te Lintelo, 2017).

Significant changes, linked to the way of life in large urban agglomerations such as Casablanca, in Morocco-due to the frequent distance between the family home and the workplaces, the salaried activities of women and the education of girls - can be read in the evolution of the eating rhythms of urban families and the assignment of gender roles. The distance from the workplace, in particular, increases consumption outside the home (Soula et al., 2020).

Likewise, "eating out" in the city is a daily affair for a large majority of residents of Mexico City and Guagalajara, Mexico. The pace of work, the long distances to be covered every day and the urban infrastructure make extra-domestic food a need to be satisfied. "Eating outside" is also a leisure activity that allows you to invest in social relationships (Soula et al., 2020). Therefore, the appropriation of public space can be observed in the case of street food, where traders and consumers give new meanings to public spaces. Thus a gardener in the public road can become the dining room of a group of young people distinguishes 
them from others. Other dimensions of "eating out" boil down to the phrase: "We eat like that, because we are Mexicans" (Soula et al., 2020).

Moreover, Quazi et al. (2010) argue that the street food industry plays an important role in cities and towns in many developing countries to meet the food demands of city dwellers in Bangladesh. It also generates jobs for a large group in the informal sector and ensures food security for low-income urban populations.

A study in Lusaka (Zambia) establishes that for street vendors, accessibility of customers is a key factor and that they strategically locate in the streets to avoid formalization costs such as rent, taxes and fees licenses (Ndhlovu, 2011). Selling street food has proven to be a viable socio-economic activity providing gainful employment for populations with limited education and skills (Sambo, 2014).

\section{Customers or Consumers of Street Food}

In Africa, many workers, employees, students, schoolchildren, etc., are customers or consumers of street food (Canet, 1997). Among them, single men under 30 are the most numerous and assiduous, along with schoolchildren and students (Canet, 1997).

Rural and urban Algerian men, under 25, take their midday and evening meals, respectively, away from home. Women go to Quick fast food (26\%) more than men (17\%) (Chikhi \& Padilla, 2014).

In Côte d'Ivoire, workers, the school population and travelers constitute a real consumer market for the street food sector (Kouamé et al., 2020). For the "garba" (popular dish made of dried cassava semolina with fried tuna), pupils, students, the unemployed, workers, the "resourceful" (people with no fixed activity) constitute the main (Soula et al., 2020).

Conversely, in Togo, street food consumers are mainly civil servants (40\%) and traders (35.11\%) and 75\% of them are men (Adjalo et al., 2020).

Out-of-home cooking in the Congo concerns the poor as well as the wealthiest city dwellers (Soula et al., 2020).

Among the Chinese, sweet industrial drinks sold in the streets are the preserve of young people between 18 and 35 years old (Soula et al., 2020).

In India (Calcutta), a survey found that out of 911 street food consumers, all were employees or students. Their monthly income ranged from US $\$ 8.33$ to $\$ 333.33$ (Chakravarty \& Canet, 1994). About $80 \%$ of the respondents were men, aged 19 to 48, with an average age of 34. Many respondents were themselves street traders (Chakravarty \& Canet, 1994). In the Writers' Building area, about $75 \%$ of office workers ate, in part, street food, 5 days a week. Most bought street food for a long time (10 months to 15 years), with different vendors and consumed it on the spot (Chakravarty \& Canet, 1994). However, according to Chakravarty and Canet (1994), only 33\% of the consumers surveyed bought street food daily, while about $23 \%$ visited the stalls one to four times a week. The other interviewees were only occasional consumers (Chakravarty \& Canet, 1994). 


\section{Street Food Vendors}

Collective or street catering is held, in Guinea Conakry, mainly by the "Fulani" (ethnic group) and the "Soussous" (ethnic group) without excluding the "Malinké" (ethnic group) and "Foresters" (ethnic group). The largest age group is 20 - 40 years old, followed by 40 - 60 years old. Women constitute $84 \%$ of the workforce of street vendors. The remaining $16 \%$ are made up exclusively of " $\mathrm{Fu}$ lani" men. The sale of drinks is carried out by street vendors who offer ice water. The dishes are served with un-iced water and soda (Drame \& Tounkara, 2000).

Street food vendors in Daloa (Côte d'Ivoire) are grouped into two categories. These are stationary vendors and street vendors. Representing $94 \%$ of all vendors, stationary vendors dominate the street food sale (Kouamé et al., 2020).

In Lomé (Togo), street catering employs a very large number of mothers who carry out this income-generating activity on their doorstep and almost all the inhabitants eat, at least once a day on the side of the road (Nutsudzie, 2018). Thus, $82.5 \%$ of street restaurateurs in Togo are women (Adjalo et al., 2020).

Street vendors in Calcutta are men aged 20 to 45 and women aged 30 to 45 . Their education levels were generally low and $21 \%$ were illiterate (Chakravarty \& Canet, 1994).

In Zambia, Lusaka, it is established that school-aged children are involved in selling food on the street (Sambo, 2014).

A study in Bangladesh shows that $25 \%$ of street vendors are illiterate and cannot write their names and have no formal education. Since the street food business requires little investment, most vendors (88\%) own the business (Quazi et al., 2010).

\section{Identification and Characterization of Street Foods}

Prepared street food dishes in Africa first include those for breakfast based on bread or sandwiches (with kebabs, omelets, butters or margarines), with coffee or tea with milk, cereal porridge, beans. Also included in breakfast are snacks, donuts, peanuts, nougats, cookies and pastries (more or less Western-style), and dairy products (curd). Then there are the main dishes for lunch or dinner, which are often the traditional foods of family menus (Canet, 1997).

These main meals are carbohydrate-based, derived from cereals, tubers, etc. They are accompanied by sauces (or frying) made up of vegetables, legumes, meat or fish. These are "tôh" (dough obtained from corn flour (millet or rice) cooked in boiling water), "foufou" (West African dish obtained from cassava, plantains or yams cooked in hot water and coarsely pounded), "foutou" (West African dish obtained from cassava, plantain or yam cooked in hot water and pounded), "attiéké" (fermented steamed cassava semolina), fatty rice, "tchèp diene" (it is a variant of the Senegalese version of fatty rice), "yassa" (West African sauce made with onion and fish/chicken), etc. Finally, in the beverage category, water in plastic bags, refrigerated or not, is the most sold. Traditional drinks such as "tchakpalo or dolo" (is an ancestral beer obtained by the fermentation of 
red sorghum or germinated millet and cooked in water, widespread in Sahelian Africa), juices (ginger, bissap, etc.) are more sold than industrial drinks (Canet, 1997).

Côte d'Ivoire has a wide range of street foods. At lunch and dinner, there are, on the one hand, the main courses accompanied by sauce (beef, bush meat, fresh fish, "kédjénou" (chicken soup), chicken with "yassa", etc.). These are the rice dishes, the "tchèp diene", "foutou" and "foufou" (of plantain or yam), couscous. On the other hand, there are the dishes with frying: the braised fish accompanied by "alloko" (grilled plantain slices) or "attiéké", "attiéké" with fried fish (or "garba") (Akindès, 1989; Soula et al., 2020).

Whole-grain coffee, whole-grain coffee and buttered bread, omelet dishes, spaghetti, peas with meat or kidney, "degue" yogurt (thick yogurt containing millet, tapioca, or chickpeas) Akindès (1989) considered to be part of breakfast often serve as lunch or dinner.

The situation in Guinea Conakry is similar to that described above. Street restaurants generally offer morning and noon meals. The dishes served are rice with sauce peanut, leaf, soup. Fonio, cassava ("attiéké", stew), "tôh," mango soup are on the menu. The meat is served separately at the request of the consumer. The leaf sauce is better served because it is more filling. On the other hand, the meat soup is more in demand but remains expensive (Drame \& Tounkara, 2000). In addition, it is prepared and sold along the streets, mango, potato and red oil. Corn porridge and "tôh" (both measured with a spoon) and yam cooked in water, are sold by street women. The plantain is sold by slices or in piles by women sitting on the sidewalks (Drame \& Tounkara, 2000).

In Benin, street sales are dominated by dairy products and fruits, which are directly consumable (Thuillier-Cerdan \& Bricas, 1998).

Initially, the Congolese street food service focused on the sale of donuts made from wheat flour, corn porridge and "maboké" (freshwater fish stewed) sold by women. Then, she offered classic local dishes including fried fish (horse mackerel), "three pieces" (a dish made up of three products, animal products, vegetables and peanut paste). But it is also full of dishes from urban cuisine invented by city dwellers. These are the "totapen broth" light sauce, composed of smoked or half-smoked fish, mixed with "koko" (tropical forest plant, of the genus Gnetum), okra and chilli (Soula et al., 2020). Traveling Congolese restaurateurs travel with lemon, vinegar, oil, salt, avocado, cucumber, green salad, tomato, bread and hard-boiled eggs that they offer to consumers. This consumption of raw vegetables by the Congolese constitutes a significant development, favored by street food. In addition, street food offers the Congolese, cowpea beans ("kwaou"), and many other foods of Ivorian, Senegalese, Cameroonian origin, etc. including "degue" yogurt, "alloko", "tchèp diene", "yassa" chicken, braised carp accompanied by "alloko", "ndolé" (Cameroon sauce, prepared with the leaves of a plant of the Asteraceae family), "DG" chicken, braised pork skin or "red carpet", pizzas and burgers (Berton-Ofouémé, 1993; Soula et al., 2020). 
Sachet and jar yogurt, fruit juices, soft drinks, orange (fruit), bread with pate, bread with margarine, sandwiches with dumplings, "tchèp diene" are part of the food of rue du Gabon. But the favorite street food dishes are "Senegalese" rice (18.7\%) and all kinds of dumplings and sandwiches (13\% and 11\%) (Monteillet, 2017).

In Mozambique, Maputo, the identified street vending sites were fixed (77.4\%) and mainly sold industrial food (51.9\%). The frequency of fruits, drinks and foods other than fruits was $24.5 \%, 32.5 \%$ and $73.9 \%$, respectively (Sousa et al., 2019).

Foods sold on the streets of Lusaka (Zambia) include fruits, raw vegetables, cooked meats and wild roots eaten for pleasure (Sambo, 2014).

In Mexico, many very famous typical dishes are marketed in the streets. These are the "pozole" (the pozole is a preparation is a broth with corn seeds and meat, mainly pork), the "flautas" (the flautas are dishes stuffed with beef, chicken, beans or potatoes and cooked by frying), "tacos" (tacos are composed of beans, stewed meats, stuffed peppers, meat broths, etc.) and "menudo" (typical tripe soup) (Soula et al., 2020).

Street food is part of the culture in Central Asia. In Tajikistan, Dushanbe, homemade and industrial street food is widely available. There are fruits, beverages and non-fruit foods available, respectively, in $4.5 \%, 40.5 \%$ and $87.4 \%$ of 800 outlets. For foods other than fruit, the majority (63.6\%) consists of homemade foods including breads, traditional dishes, snacks, pastries, sandwiches and cakes. Food exclusively industrial represents 19.3\%: bread, snacks, pastries and biscuits. Both types of food account for $17.1 \%$ of sales (Albuquerque et al., 2019).

The wide availability of street food in Bishkek (Kyrgyzstan) underlines its importance for this urban population. Traditional snacks, dishes and drinks coexist with more westernized products. Fruits, beverages, and non-fruit foods were available at $4.0 \%, 61.7 \%$ and $81.0 \%$ of retail locations, respectively (Albuquerque et al., 2020). Among those who sold food other than fruit, some (56.5\%) sold only homemade or traditional foods such as bread, main courses, snacks, pastries, sandwiches and cakes. Others $(23.3 \%)$ sold both homemade or traditional and processed foods. There are also those who offer (20.2\%) only industrial foods including bread, snacks, pastries, cakes and cookies. Tea and soft drinks were available at over $50 \%$ of beverage outlets (Albuquerque et al., 2020).

\section{Street Food and Street Food Sales Sites in Schools and among Children}

There are various street food sales sites in Congo with customers of diverse social status. The "maléwas" are places of sale, at the edge of the main roads, of dishes prepared at home. The catering is done in the open air or under a basic shelter made with tarpaulins and banners of recovery or fabrics. They are mainly frequented by low-income consumers. "Typhoïdes" are popular restaurants frequented by low to medium socioeconomic consumers. They are characterized by 
the exposure of food to flies, vectors, among others, of typhoid fever. The "Nganda", in the north of the Congo, refers to the bivouacs of fishermen. In urban areas, it refers to bars that offer ready-made meals to consumers. The "nganda" are frequented by all sections of the population. There are also Western or European type out-of-home kitchens, originally serving mostly sandwiches, which have evolved into more elaborate and complex "ready-to-eat" foods complexes (Soula et al., 2020).

In Guinea (Conakry), collective or street catering is found in various places: courtyards of family houses, sidewalks and solid buildings (Drame \& Tounkara, 2000).

Here are some street food sales sites in the Côte d'Ivoire: the "maquis" (the maquis are popular dining areas, with a family and friendly atmosphere), the "kiosks" (place for food in planks and rafters) or container (Akindès, 1989), the "garbadromes" (these are barracks where the "garba" is sold and whose salubrity leaves much to be desired), the "plein-air" (open-air dining places or under trees) (Soula et al., 2020).

In Bangladesh, the sale of street food is done in vending shops (68\%) were located on sidewalks, carts (over 30\%) (Quazi et al., 2010).

In China, the middle class consumes sugary industrial drinks in many places of mobility including kiosks, grocery stores, mini markets, vending machines. However, restaurants, cafes, pastry shops and bakeries or even beverage shops are important places for the consumption of sweet, industrial or more artisanal drinks (Yang, 2006).

In Maradi (Niger) and Bamako (Mali), the consumption of food bought in the street for preschool children would be one of the elements likely to explain the lack of difference in the prevalence of malnutrition among children of families rich and poor (Raynaut, 1992).

Chauliac et al. (1998) indicate that out of 240 children enrolled in the fourth year of primary school in Cotonou, $218 \%$ or $90.8 \%$ of them declare that they regularly have a nest egg to buy food from accredited vendors in Cotonou. their school or on the street. The average weekly amount of this nest egg is 250 FCFA (Franc African Financial Community) (US \$0.5) per child.

In Brazil, in school canteens, students receive $70 \%$ of their daily nutritional needs through 3 or 4 meals. The majority of students (73\%) have a normal body mass index. soft drinks and other sweets are prohibited among schoolchildren eating in canteens (FAO, 2014a).

The opposite is true in Japan and Mexico where their school feeding programs have been reformed to address the growing problem of overweight children (Harper et al., 2008).

In Gabon, street food is associated with significant obesity in adolescent girls (10\% of cases), although progress has been made, hygiene problems related to street products persist (Monteillet, 2017).

In Nicaragua, school meals were simple and monotonous-rice, beans and a 
cereal drink-and children were given the same all the time. About $22 \%$ of children between 6 - 9 years old in Nicaragua suffered from chronic malnutrition. But corrections have been made so that now children eat eggs twice a week, as well as fruits and vegetables supplied by local farmers (FAO, 2014a).

\section{Nutritional Value of Street Foods}

In Côte d'Ivoire, criticism of the nutritional and hygienic quality of "garba" has been decried by some middle-class consumers and is reinforced by scientific surveys Koffi et al. (2015). There appears to be an overuse of oil for frying fish, which can affect the quality of the fish.

Consumption outside the home, among Gabonese adolescents, consisting of foods rich in fat and energy, sweets and foods low in fiber is frequent (30\%) (Monteillet, 2017).

In Maputo (Mozambique), street food is dominated by junk food. Fried cakes were the most energetic $(430 \mathrm{kcal} / 100 \mathrm{~g})$, the highest in fat $(21.0 \mathrm{~g} / 100 \mathrm{~g})$ and carbohydrates $(53.4 \mathrm{~g} / 100 \mathrm{~g}$ ) (Sousa et al., 2019). The most abundant protein sources were in meat/fish/liver casseroles (10.7 - $11.6 \mathrm{~g} / 100 \mathrm{~g})$. Fried cakes had the lowest sodium $(90 \mathrm{mg} / 100 \mathrm{~g})$ and potassium $(81 \mathrm{mg} / 100 \mathrm{~g})$ content; while burgers had the highest content of these micronutrients $(455 \mathrm{mg} / 100 \mathrm{~g}$ and 183 $\mathrm{mg} / 100 \mathrm{~g}$, respectively). Cooked liver dishes had the highest sodium/potassium ratio (11.95). Fried snacks had the highest content of trans fatty acids $(0.20$ g/100g) (Sousa et al., 2019).

The nutritional value of street foods was assessed by analyzing some popular dishes in Calcutta (India). An average $500 \mathrm{~g}$ meal contained 20 to $30 \mathrm{~g}$ of protein, 12 to $15 \mathrm{~g}$ of vegetable fat and 174 to $183 \mathrm{~g}$ of carbohydrates and provided approximately $1000 \mathrm{kcal}$. Street food, costing US \$0.33, provides about $200 \mathrm{kcal}$, including $25 \mathrm{kcal}$ of protein, $144 \mathrm{kcal}$ of carbohydrates, and $31 \mathrm{kcal}$ of lipids (100\% vegetable fat in a vegetarian diet; $80 \%$ vegetable fat and $20 \%$ animal fat in a diet) (Chakravarty \& Canet, 1994).

Street food in "kampung" (villages), Jakarta (Indonesia), produces so-called "obesogenic" environments that facilitate the consumption of high-calorie foods (Anggraini et al., 2016).

In Dushanbe (Tajikistan), homemade and industrial street food has heterogeneous nutritional values. Homemade foods (breads, traditional dishes, snacks, pastries, sandwiches and cakes) had higher energy per serving than industrial foods (bread, snacks, pastries and biscuits): on average $452 \mathrm{kcal} /$ serving against $276 \mathrm{kcal} /$ portion (or $18911155 \mathrm{~kJ} /$ portion against $1155 \mathrm{~kJ} /$ portion, $p<0.001$ ). High in saturated fatty acids (soup: $10.9 \mathrm{~g} /$ serving) and trans fatty acids (cakes: $1.8 \mathrm{~g} / \mathrm{serving}$ ) have also been found in homemade foods. However, industrial wafers showed the highest content of saturated fatty acids (12.9 g/serving) and trans fatty acids (2.5 g/serving) (Albuquerque et al., 2019).

The nutritional value of some street foods in Kyrgyzstan (Bishkek) was carried out by Albuquerque et al. (2020). Homemade or traditional foods (bread, main 
dishes, snacks, pastries, sandwiches and cakes) had the highest energy/serving (median kcal/serving: 357 vs. 145, $p<0.001$ ). A high content of saturated and trans fatty acids has been observed in some traditional homemade dishes and snacks, reaching $30.2 \mathrm{~g} /$ serving and $2.9 \mathrm{~g} /$ serving, respectively (in the homemade "manty", a traditional dish). The variability in energy, macronutrients and lipid profile of artisanal and industrial products reflects heterogeneous cooking practices and ingredients.

\section{Economics and Cost of Street Food}

In Africa, out-of-home catering accounts for $2 \%$ of jobs in the food economy. This share varies considerably from country to country. In Senegal and Ghana, it represents $6 \%$ and $4 \%$, respectively, against $1 \%$ and less in Niger and Mali. These figures reflect the differences in household spending. In the main cities, out-of-home catering represents a large but variable part of food expenditure, ranging from over 30\% in Abidjan, Cotonou and Lomé to less than 10\% in Bamako, Conakry and Freetown (Bricas et al., 2016). These differences can be explained by cultural factors, but also by the size, configuration of cities, transport network and working hours. Allen et al. (2018) estimate that in Africa, out-of-home catering accounts for $10 \%$ of all non-farm jobs in the food economy, with significantly higher shares in some urban areas in Africa.

In Côte d'Ivoire, the price of a basket (around $30 \mathrm{~kg}$ ) of "attiéké de garba" varies between 4000 and 7000 CFA francs (US $\$ 8$ and US \$14) (Soula et al., 2020). In addition, savings of 500 CFA francs (US $\$ 1$ ) are made by consumers of "garba" on each dish consumed, thanks to the economic value of the food (Koffi, 2021).

The pork skin grillers or "red carpet" of Congo adapt to the economic conditions of city dwellers by selling cuts at all prices (from 50 CFA francs, or US \$0.1) (Soula et al., 2020).

For an average weekly food expenditure per household in Cotonou (Benin) of 4145 FCFA (US \$8.29), 1091 FCFA (US $\$ 2.18$ ) or more than a quarter (26.3\%), are devoted to catering expenses. and street food (Thuillier-Cerdan \& Bricas, 1998). For an average weekly food expenditure per household in Cotonou (Benin) of 4145 FCFA (US \$8.29), 1091 FCFA (US \$2.18) or more than a quarter (26.3\%), are devoted to catering expenses and street food (Chauliac et al., 1998).

Table 1 shows prices of some street foods in Gabon.

In Guinea (Conakry), the simple rice dish is generally sold at 500 FG (Guinean franc) (US \$0.05) and 1000 FG (US \$0.1) if served with meat or fish. The average profit that restaurateurs make per day is 6650 FG (US \$0.665) (Drame \& Tounkara, 2000).

In Calcutta (India), street meals cost between US $\$ 0.13$ and US $\$ 0.27$ (US $\$ 0.16$ ). Thus, it appears that street foods may be the cheapest way to obtain a nutritionally balanced meal outside the home, provided the consumer is informed and able to choose the right combination of foods (Chakravarty \& Canet, 1994). 
Table 1. Price of some street foods sold on the public highway in Libreville (Gabon).

\begin{tabular}{ccc}
\hline Food & Portion ing & Price in FCFA (in US \$) \\
\hline Sachet yoghurt & 100 & $100(0.2)$ \\
Yoghurt in a jar & 100 & $250(0.5)$ \\
Orange fruit & 141 & $200(0.4)$ \\
Fruit juice & 250 & $300(0.6)$ \\
Soft drink & 330 & $350(0.7)$ \\
Bread and pate & 134 & $200(0.4)$ \\
Margarine bread & 112 & $200(0.4)$ \\
Dumpling sandwich & 180 & $500(1)$ \\
“Tchèp diene" & 629 & $1200(2.4)$ \\
\hline
\end{tabular}

Source: Monteillet, 2017.

\section{Preparation, Contamination and Health Risks of Street Food}

Street food has many shortcomings, the main ones being the anarchic occupation and unsanitary conditions of preparation and sale places, but also and above all the problem of the sanitary quality of food due to non-compliance or ignorance of hygiene rules when preparing and selling food (Yasmeen, 2001; Barro et al., 2002a, 2002b). Several studies on street foods and those in canteens have revealed the presence of viruses (hepatitis A virus, Rotavirus, Norovirus), pathogenic bacteria such as Escherichia coli, Shigella sp, Salmonella sp, Staphylococcus aureus, Streptococcus sp, Vibrio cholerea, Bacillus cereus, Campylobacter spp, Yersinia enterocolitica, Clostridium perfringens and Listeria monocytogenes at worrying numbers (King et al., 2000; El-Scherbeeny et al., 1985a, 1985b; Dawson \& Canet, 1991). These results were confirmed by other analyzes showing insufficient microbiological quality, increasing the risk of poisoning (King et al., 2000; Barro et al., 2002a; Cardinale et al., 2005).

According to Meva'a et al. (2000), street food carries an increasingly worrying health risk in Daloa, a metropolitan area in Côte d'Ivoire. On the normative level, it is often noticed that the conditions of preparation and sale of "garba", a highly popular dish, marketed in the street, can be a source of health risks for consumers, in particular cancer, cardiovascular diseases, high blood pressure and obesity (Bhattacharya et al., 2008; Soula et al., 2020). In addition, the main components (tuna, "attiéké", fresh vegetables and oil) intended for the production of "garba" would exceed food hygiene standards in Côte d'Ivoire these standards (Koffi, 2021).

The limited education demonstrated by food vendors in Lusaka (Zambia) implied a corresponding lack of basic food safety and hygiene skills (Sambo, 2014).

In India, street foods were prone to microbiological contamination (Chakravarty \& Canet, 1994). The same is true in Bangladesh where street food vendors 
are often poor, uneducated and cannot appreciate good food preparation practices. Therefore, street food is seen as a major risk to public health. Microbial analysis reveals significant part of drug resistant bacteria Spread In community through street food (Quazi et al., 2010).

In Mexico, the health dimension of "eating out" has two main elements linked to the concept of risk. First, "eating out" is perceived to carry long-term risks, linked to the adverse health consequences of heavy food intake from out-of-home diets. Second, "eating out" carries more immediate risks associated with eating something that we do not know the source or the hygienic conditions of the preparation (Soula et al., 2020).

In Espírito Santo (Brazil), the sanitary conditions of street food were controlled according to the resolution of Brazilian law 216/2004. Out of 200 points of sale evaluated, $58.5 \%$ were classified as bad, with unsatisfactory hygiene conditions. The main shortcomings were linked to the seller's hygienic conditions. Of the 63 food samples analyzed, $57.1 \%$ showed contamination above the limit allowed by law and were unfit for consumption. The evaluation of good handling practices and the microbial quality of street foods revealed that street foods are a source of health risk for consumers and a public health problem (Ferrari et al., 2021).

However, Von Holy and Makhoane (2006) found that South African street vendors were able to produce relatively safe foods with low bacterial counts, although there is still a need for good hygienic and safe conditions. Access to basic sanitation facilities.

\section{Street Food Packaging and Environmental Consequences}

The term packaging refers to the techniques and materials used to wrap or protect products for distribution, storage, sale or use (Soroka, 2002).

Innovations and responses today to changing consumer preferences and demands have added to the function of mere protection functions of promotion, information, convenience, education and manipulation (FAO, 2014b).

In Africa, poor techniques for preparing, packaging, preserving and selling food in a precarious environment (lack of drinking water, proximity to wastewater evacuation routes, sewers and piles of garbage, or excessive sunshine) may also be the source of microbiological contamination of street foods. In addition, there are consequences on the urban environment attributable to the preparation and sale of food on public roads. These are fumes from kitchens, obstructions in sanitation networks, congestion and degradation of traffic routes (streets and sidewalks), garbage and wastewater dumped on public roads. This thus worsens the already precarious situation of the infrastructure of cities in African countries (the lack of drinking water supply and means of evacuating waste and wastewater) (Canet, 1997).

The spatial practices of street catering and the use of plastic bags have negative environmental consequences on Cocody, a residential municipality in Abidjan 
(Côte d'Ivoire). For this, the Ivorian government issued a decree prohibiting this plastic packaging following the eviction operations favored in Cocody (Bodo et al., 2016).

In her work, Bénié (2013) listed 34 foods for which Ivorian vendors use vegetable packaging. Foods packaged with vegetable leaves in decreasing order of importance are "dockounou" (cooked corn dough mixed with spices and fishmeal) (29\%), attiéké (23\%), taro "foutou" (5.1\%) and "bolo" (corn or rice paste, sweet, stewed) (4.2\%), "fari" (traditional West African dish) (3\%), taro porridge (3\%) and "akassa" (corn or rice paste, stewed) $(2.5 \%)$ and other foods $(<2.5 \%)$. In total, the different plant species are used as food packaging foils in Côte d'Ivoire. Here are the main plant species: Thaumatococcus daniellii (58\%), Musa para disiaca et Musa Sp (28.5\%), de Tectona grandis (5.7\%) et de Zea mays (3.7\%). The proliferation of non-biodegradable packaging has harmful consequences on the environment (pollution, unsanitary conditions and clogging of gutters) and on health (public health). Bénié (2013) suggests the valorization of biodegradable vegetable vegetable packaging for foodstuffs in almost all rural and urban markets in Côte d'Ivoire.

In Togo, in street catering, plastic packaging is used to meet the food needs of the urban population. The use of this packaging has adverse effects on the sanitation system of West African cities , including Lome' (Adjalo et al., 2020).

\section{Regulation of Street Food}

In Africa, according to Canet (1997), all African street food actors operate under unwritten rules: the verbal contract constitutes the legal engine of the informal sector. Likewise, the sale of food on the street is not regulated in Bangladesh. There is no policy that can facilitate access to street entrepreneurship where the sale of food in the street can also be understood as a means of employment for people marginalized from the formal labor market. Street vendors frequently face harassment and restrictions (Quazi et al., 2010).

A study in Lusaka, Zambia recommended that the government enact regulations that will allow the sale of street food to thrive within established guidelines (Sambo, 2014). Similarly, in Dushanbe (Tajikistan), Albuquerque et al. (2019) encourage the establishment of policies promoting the availability of healthy street foods.

In Calcutta (India), there is a structure to license, inspect and regulate the catering industry. However, the street food sector is not a legal entity there and food control activities are limited to occasional complaints. Guided by consumer imperatives, vendors attempt to meet their customers' demands regardless of food inspection rules (Chakravarty \& Canet, 1994).

On the occasion of the COVID 19 pandemic, a decree was instituted in Gabon setting out the emergency measures applicable to establishments and businesses in the food sector during the COVID 19 confinement period (Offi- 
cial Journal 2020-63) Order n 007/MAEPA of 03 April 2020 (Droit Afrique, 2021).

\section{Conclusion}

Street food is an essentially urban activity involving mainly the poorest sections of the population in many countries. It offers consumers less expensive meals of approximate hygienic and nutritional qualities, and generates financial resources for sellers.

However, in view of the many health and environmental risks raised by this activity, it is urgent to first do more research on the hygienic and nutritional qualities of street foods. Next, the street food sector needs to be regulated at dietary, product packaging and vendor levels. Finally, there is a need to organize this sector in terms of taxation and price, in addition to the spatial distribution of sales sites.

\section{Conflicts of Interest}

The authors declare no conflicts of interest regarding the publication of this paper.

\section{References}

Adjalo, D. K., Houedakor, K. Z., \& Zinsou-Klassou, K. (2020). Usage des Emballages Plastiques dans la Restauration de Rue et Assainissement des Villes Ouest-Aricaines: exemple de Lomé au Togo. International Journal of Biological and Chemical Sciences, 14, 1646-1656.

Akindès, F. (1989). Le Secteur Informel Alimentaire à Abidjan. La lettre de Solagral-Stratégies Alimentaire, No. 30, 10-13.

Akindes, F. (1991). Restauration Populaire et Sécurité Alimentaire à Abidjan. Cahier des Sciences Humaines, 27, 169-179.

Albuquerque, G., Lança de Morais, I., Gelormini, M., Casal, S., Damasceno, A., Pinho, O. et al. (2019). Street Food in Dushanbe, Tajikistan: Availability and Nutritional Value. British Journal of Nutrition, 122, 1052-1061. https://doi.org/10.1017/S0007114519001892

Albuquerque, G., Lança de Morais, I., Gelormini, M., Sousa, S. C., Pino, O., Moreira, P. et al. (2020). Macronutrient Composition of Street Food in Central Asia: Bis N., Kyrgyzstan H. Food Science \& Nutrition, 8, 5309-5320. https://doi.org/10.1002/fsn3.1753

Allen, T., Heinrigs, P., \& Heo, I. (2018). Agriculture, Alimentation et Emploi en Afrique de l'Ouest. Notes ouest-africaines, No. 14. Éditions OCDE.

Anggraini, R., Februhartanty, J., Bardosono, S., Khusun, H., \& Worsley, A. (2016). Food Store Choice among Urban Slum Women is Associated with Consumption of Energy-Dense Food. Asia Pacific Journal of Public Health, 28, 458-468. https://doi.org/10.1177/1010539516646849

Barro, N., Nikiéma P., Ouattara, C.A.T., \& Traoré A.S. (2002a). Evaluation de l'Hygiène et de la Qualité Microbiologique de quelques Aliments Rue et les Caractéristiques des Consommateurs dans les Villes de Ouagadougou et de Bobo-Dioulasso (Burkina Faso). Rev. Sci Tech. Sci. Santé, 25, 7-21.

Barro, N., Ouattara, C. A. T., Nikiéma, A. P., Ouattara, A. S., \& Traoré, S. A. (2002b). Evaluation de la Qualité Microbiologique de quelques Aliments de Rue dans la Ville de 
Ouagadougou au Burkina Faso. Cahier Santé, 12, 369-374.

Bénié, C. K. D. (2013). Emballage et Sécurité des Aliments. Diversité des Aliments Emballés et des Feuilles Végétales Utilisées en Côte d Ivoire. Mémoire de Master Microbiologie et Biotechnologie des Aliments, Université Nangui Abrogoua.

Berton-Ofouémé, Y. (1993). Identification des Comportements Alimentaires des Ménages Congolais de Brazzaville: Stratégies Autour des Plats. In J. Muchnik (Éd.), Alimentation, techniques et innovations dans les régions tropicales (pp. 167-175). L'harmattan.

Berton-Ofoueme, Y. (2007). La restauration "Populaire" dans la Conurbation Cotonou/Porto Novo/Abomey-Calavy (Benin). Revue du CAMES-Nouvelle Série B, No. 2, 323-237.

Bhattacharya, A. B., Sajilata, M. G., Tiwari, S. R., \& Singhal, R. (2008). Regeneration of Thermally Polymerized Frying Oils with Adsorbents. Food Chemistry, 110, 562-570. https://doi.org/10.1016/j.foodchem.2008.02.033

Bodo, K. R. J., Dakouri, G. D. F., \& Aloko, N. J. (2016). L'usage des Sachets Plastiques dans la Restauration de Rue à Cocody: Un Gros Polluant de l'Environnement. Revue ivoirienne d'anthropologie et de sociologie, No. 31, 231-248.

Bricas, N. (1993). Les Caractéristiques et l'Evolution de la Consommation Alimentaire dans les Villes Africaines. Conséquences pour la valorisation des produits vivriers. In Muchnik (Éd.), Alimentation, techniques et innovations dans les régions tropicales (pp. 127-160). L'Harmattan.

Bricas, N., Tchamda, C., \& Mouton, F. (2016). "L'Afrique à la Conquête de son Marché Alimentaire Intérieur. Enseignements de dix ans d'Enquete auprès des Ménages d'Afrique de l'Ouest, du Cameroun et du Tchad". Études de l'Agence française de développement, No. 12. http://www.afd.fr/

Canet, C. (1997). L'Alimentation de Rue en Afrique. Revue "Aliments dans les villes", 2, 1-17.

Cardinale, E., Perrier Gros-Claude, J. D., Tall, F., Gueye, E. F., \& Salvat, G. (2005). Risk Factors for Contamination of Ready-to-Eat Street-Vended Poultry Dishes in Dakar, Senegal. International Journal of Food Microbiology, 103, 157-165. https://doi.org/10.1016/j.ijfoodmicro.2004.12.023

Chakravarty, I., \& Canet, C. (1994). Street Foods in Calcutta. Food and Agriculture Organization of the United Nations.

Chauliac, M., Bricas, N., Ategbo, E., Amoussa, W., \& Zohoun, I. (1998). Alimentation Hors du Domicile des Ecoliers de Cotonou. Cahier Santé, 8, 101-108.

Chikhi, K., \& Padilla, M. (2014). L’Alimentation en Algérie. Quelles Formes de Modernité? New Medit, Ciheam-Iamb, 13, 50-58. hal-02163637

Dawson, R. J., \& Canet, C. (1991). International Activities in Street Food. Food Control, 2, 135-139. https://doi.org/10.1016/0956-7135(91)90081-7

Delisle, H. (1991). Les styles alimentaires urbains. Alimentation, nutrition et agriculture, 1, 7-10.

Drame, B. S., \& Tounkara, O. (2000). Evolution de la Consommation Alimentaire à Conakry.

Droit Afrique (2021). Gabon Mesures d'Urgence Applicables aux Etablissements et Commerces du Secteur Alimentaire. Arrété n007/MAEPA du 03 avril 2020.

http://www.droit-afrique.com

El-Scherbeeny, M. R., Saddik, M. F., \& Bryan, F. L. (1985a). Microbial Profiles of Food Sold by Street Vendors in Egypt. International Journal of Food Microbiology, 2, 355-364. https://doi.org/10.1016/0168-1605(85)90026-1

El-Scherbeeny, M. R., Saddik, M. F., Aly, H. E. S., \& Bryan, F. L. (1985b). Microbial pro- 
files and storage temperatures of Egyptian rice dishes. Journal of Food Protection, 48, 39-43. https://doi.org/10.4315/0362-028X-48.1.39

FAO (Food and Agriculture Organization of the United Nations) (1990). L'Alimentation de Rue en Afrique. Food and Agriculture Organization of the United Nations.

FAO (Food and Agriculture Organization of the United Nations) (2007). Les Bonnes Pratiques d'Hygiène dans la Préparation et la Vente des Aliments de Rue en Afrique (pp. 1-17). Food and Agriculture Organization of the United Nations.

FAO (Food and Agriculture Organization of the United Nations) (2014a). Généraliser le Modèle Brésilien de l'Alimentation Scolaire. Food and Agriculture Organization of the United Nations.

FAO (Food and Agriculture Organization of the United Nations) (2014b). Solutions d'Emballage Alimentaire Adaptées aux Pays en Développement (pp. 1-44). Food and Agriculture Organization of the United Nations.

Ferrari, A. M, Oliveira, J. S.C., \& São José, J. F. B. (2021). Street Food in Espírito Santo, Brazil: a Study about Good Handling Practices and Food Microbial Quality. Food Science and Technology, 1-8. https://doi.org/10.1590/fst.31620

Gerbouin-Rerolle, P., Chauliac, M., \& Masse-Raimbault, A. M. (1993). Alimentation de Rue: Situation et Perspectives. Cahier Santé, 3, 367-374.

Harper, C., Wood, L., \& Mitchell, C. (2008). The Provision of School Food in 18 countries. The School Food Trust.

http://www.childrensfoodtrust.org.uk/assets/research-reports/school_food_in18countri es.pdf

High Level Panel of Experts (2017). Nutrition and Food Systems. High Level Panel of Experts on Food Security and Nutrition of the Committee on World Food Security.

King, L. K., Awumbila, B., Canacoo, E. A., \& Ofosu-Amaah, S. (2000). An Assessment of the Safety of Street Foods in the Ga district of Ghana; Implication for the Spread of Zoonoses. Acta Tropica, 76, 39-43. https://doi.org/10.1016/S0001-706X(00)00087-5

Koentjaraningrat (2007). Villages in Indonesia. Equinox Publication.

Koffi, A. L. J. (2021). Consommation du “Garba” en Côte d'Ivoire: Entre Risques Sanitaires et Construction de Lien Social. European Scientific Journal, 17, 230-246. https://doi.org/10.19044/esj.2021.v17n19p230

Koffi, A. L. J., Fokou, G., Yao, G. R., \& Bonfoh, B. (2015). Dynamique des Habitudes Alimentaires et Gestion des Risques Socio-Sanitaires liés à la Consommation du "Garba" dans le Secteur Informel Urbain d'Abidjan. Rapport biannuel 2014-2015, Centre suisse de recherches scientifiques en Côte d'Ivoire.

Kolopaking, R., Bardosono, S., \& Fahmida, U. (2011). Maternal Self-efficacy in the Home Food Environment: A Qualitative Study among Low-Income Mothers of Nutritionally at-Risk Children in an Urban Area of Jakarta, Indonesia. Journal of Nutrition Education and Behavior, 43, 180-188. https://doi.org/10.1016/j.jneb.2009.10.010

Kouamé, Y. A., Konan, A. Z., Kouassi, K., \& Koffi, G. R. Y. (2020). Alimentation de Rue et Risques Sanitaires à Daloa (côte d'Ivoire). Revue Espace, Territoires, Sociétés et Santé, 3, 25-40.

Meva'a, A. D., Akouango, P., \& Matouty P. (2020). Consommation Alimentaire et Vulnérabilité Sanitaire. Revue Espace, Territoires Sociétés et Santé, 3, 2-11.

Monteillet, N. (2017). Alimentation Hors Domicile et Santé à Libreville: le Cas des Adolescents et Adultes Fang de Libreville. Health Sciences and Disease, 18, 116-125.

Ndhlovu, P. K. (2011). Street Vending in Zambia: A case of Lusaka District. Memorie of 
Masters of Arts in Development Studies, University of Zambia.

Nutsudzie, C. (2018). Au Togo: Relier Paysans et Restauratrices de Rue. Congressional Fire Services Institute.

Ohiokpehai, O. (2003). Nutritionnal Aspects of Street Foods in Botswana. Pakistan Journal of Nutrition, 2, 76-81. https://doi.org/10.3923/pin.2003.76.81

Protschky, S. (2008). The Colonial Table: Food, Culture and Dutch Identity in Colonial Indonesia. Australian Journal of Politics \& History, 54, 346-357. https://doi.org/10.1111/j.1467-8497.2008.00501.x

Quazi, F., Quazi, F. H., Hossain, U. S., \& Shamima, B. (2010). Institutionalization of Healthy Street Food System in Bangladesh: A Pilot Study with Three Wards of Dhaka City Corporation as a Model, Final Report. Food Planning and Monitoring Unit.

Raynaut, C. (1992). Approches Sociales de l'Alimentation Infantile. Enfant Milieu Trop, 201.

Sambo, C. G. (2014). An Ethical Assessment of Street Food Vending in Lusaka's Central Business District. Memorie of Master of Arts in Applied Ethics, University of Zambia.

Secke, C. (2007). Contribution à l'eEtude de la Qualité Bactériologique des Aliments Vendus sur la Voie Publique de Dakar. EISMV de Dakar, Sénégal.

Soroka, W. (2002). Fundamentals of Packaging Technology (3rd ed.). Institute of Packaging Professionals.

Soula, A, Yount, A. C., Lepillier, O., \& Bricas, N. (2020). Manger en ville: Regards SocioAnthropologiques d'Afrique, d'Amérique latine et d'Asie (pp. 1-172). Editions Quae. https://doi.org/10.35690/978-2-7592-3091-4

Sousa, S., Gelormini, M., Damasceno, A., Lopes, S. A., Chongole, C., Muholove, P. et al. (2019). Street Food in Maputo, Mozambique: Availability and Nutritional Value of Homemade Foods. Nutrition and Health, 25, 37-46. https://doi.org/10.1177/0260106018816427

Staatz, J., \& Hollinger, F. (2016). West African Food Systems and Changing Consumer Demands. West African Papers, OECD Publishing, Paris. http://dx.doi.org/10.1787/b165522b-en

Steyn, N. P., Mchiza, Z., Hill, J., Davids, Y. D., Venter, I., Hinrichsen, E. et al. (2014). Nutritional Contribution of Street Foods to the Diet of People in Developing Countries: A Systematic Review. Public Health Nutrition, 17, 1363-1374.

https://doi.org/10.1017/S1368980013001158

Te Lintelo, D. J. H. (2017). Enrolling a Goddess for Delhi's Street Vendors: The MicroPolitics of Policy Implementation Shaping Urban (In)formality. Geoforum, 84, 77-87. https://doi.org/10.1016/j.geoforum.2017.06.005

Thuillier-Cerdan, C., \& Bricas, N. (1998). La Consommation et la Distribution Alimentaire à Cotonou (Bénin). Collection Aliments dans les villes.

Van 't Riet, H., den Hartog, A. P., Hooftman, D. A. P., Foeken, D. W., Mwangi, A. M., \& van Staveren, W. A. (2003). Determinant of Non-Home prepared Food Consumption in Two Low Income Areas in Nairobi. Nutrition, 19, 1006-1012. https://doi.org/10.1016/S0899-9007(03)00183-7

Von Holy, A., \& Makhoane, F. M. (2006). Improving Street Food Vending in South Achievements and Lessons Learned Africa. International Journal of Food Microbiology, 111, 89-92. https://doi.org/10.1016/j.ijfoodmicro.2006.06.012

Warde, A., \& Martens, L. (2000). Eating Out: Social Differentiation, Consumption and Pleasure. Cambridge University Press. https://doi.org/10.1017/CBO9780511488894

Yang, X. (2006). La Fonction Sociale des Restaurants en Chine. L'Harmattan. 
Yasmeen, G. (2001). Workers in the Urban "Informal" Food Sector: Innovative Organizing Strategies. Food Nutrition and Agriculture, 29, 32-41.

Yulia, Khusun, H., \& Fahmida U. (2016). Dietary Patterns of Obese and Normal-Weight Women of Reproductive Age in Urban Slum Areas in Central Jakarta. British Journal of Nutrition, 116, S49-S56. https://doi.org/10.1017/S0007114516000015 